\title{
NOTES
}

\section{A NOTE ON WALT WHITMAN'S PROBABLE READING OF ROBERT CHAMBERS}

One source of a striking set of images in Walt Whitman's first edition of Leaves of Grass appears to be a thorough assimilation of ideas now recognized as the theory of evolution. ${ }^{1}$ Yet, if one notes that Leaves of Grass came out in 1855 and remembers enough history of science to know that Charles Darwin's Origin of Species was not published until 1859, one wonders where in the "long foreground" Whitman learned about what geological textbooks of the period referred to as the theory of "transmutation of species." That science was not a peripheral interest of the poet has long ago been made clear by Alice Lovelace Cooke and Joseph C. Beaver, ${ }^{2}$ and publications celebrating the centennial of Origin of Species by Loren Eiseley, Arthur O. Lovejoy, and Milton Millhauser are convincing in their argument that well before 1859 evolution was "in the air." ${ }^{3}$ The question, then, for readers of Whitman, is what sources gave the poet the thorough assurance which could lead him to proclaim:

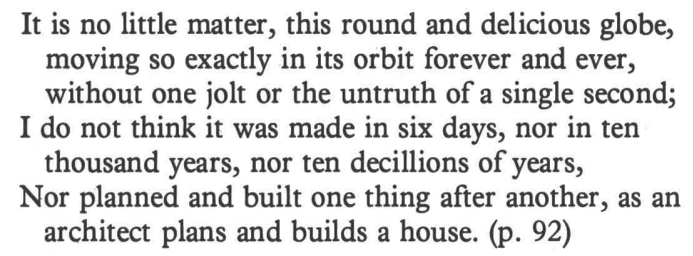

I would like to suggest that the likeliest source for Whitman's understanding of such phenomena was Robert Chambers's anonymously published Vestiges of the Natural History of Creation. ${ }^{4}$ First of all, Eiseley and Lovejoy have thoroughly documented the book's enormous popularity and its scientific veracity. Although Floyd Stovall found no evidence that Whitman had clipped any of the numerous reviews of the book, he suggested that Whitman's ideas about evolution were "directly or indirectly" derived from Vestiges of Creation. ${ }^{5}$ Millhauser earlier cited it as the most probable place for an amateur to have encountered an emphasis on embryonic change as an instrument of transmutation. ${ }^{6}$ All who now write about Chambers identify him as an able popularizer whose gift for synthesizing and then explaining current ideas made him the person who opened the way for understanding and acceptance of evolutionary theory. As I hope this paper will show, there are enough intriguing similarities in words and phrases between Chambers and Whitman to advance the argument further that the poet was familiar with Vestiges.

Critics fulminated against the Vestiges of Creation, a book that was to draw most of the venom that might have been used against Darwin, but the public read it with eagerness and enthusiasm. Although not a professional scientist, Chambers made an impressive case for evolution. Certainly a book this popular is worth examination as at least representative of the kind of material available to Whitman before 1859. A quick glance at the poems included in the first edition of Leaves of Grass reveals that Whitman's concept of creation is not Biblical and that he often joins what was known as the nebular hypothesis to geological data. Therefore, the imagery of space, time 
and earth is fused. When he talks about beginnings and the seemingly infinite amount of time behind us, he is not just referring to the advent of humans or even of the earth but of the entire universe:

My embryo has never been torpid. ... nothing could overlay it;

For it the nebula cohered to an orb. ... the long slow strata piled to rest it on. . . vast vegetables gave it sustenance,

Monstrous sauroids transported it in their mouths and deposited it with care. (p. 50)

Since Chambers was neither a geologist nor an astronomer but a popularizing journalist, he could survey the whole field. Concerned as he was about beginnings, he began in space; his first chapter is titled "The Bodies of Space, Their Arrangements and Formation." Chambers provided for the origins of the universe before he discussed developments on earth; he was a proponent of the nebular hypothesis.

Of nebulous matter in its original state we know too little to enable us to suggest how nuclei should be established in it. But, supposing that, from a peculiarity in its constitution, nuclei are formed, we know very well how, by virtue of the law of gravitation, the process of an aggregation of the neighboring matter to those nuclei should proceed, until masses more or less solid should become detached from the rest. It is a well known law in physics that, when fluid matter collects towards or meets in a centre, it establishes a rotary motion. See minor results of this law in the whirlwind and the whirlpool-nay, on so humble a scale as the water sinking through the aperture of a funnel. It thus becomes certain that when we arrive at the stage of a nebulous star, we have a rotation on an axis commenced. (pp. 9-10)

This leads us at once to the conclusion that the whole of our firmament was at one time a diffused mass of nebulous matter, extending through the space which it still occupies. So also, of course, must have been the other astral systems. Indeed, we must presume the whole to have been originally in one connected mass, the astral systems being only the first division into parts, and solar systems the second.

The first idea which all this impresses upon us is, that the formation of bodies in space is still and at present in progress. We live at a time when many have been formed, and many are still forming. Our own solar system is to be regarded as completed, supposing its perfection to consist in the formation of a series of planets, for there are mathematical reasons for concluding that Mercury is the nearest planet to the sun, which can, according to the laws of the system, exist. (p. 15)

Whitman is not only aware that "there is no stoppage, and never can be stoppage," but there shall be men and women who "stand cool and supercilious before a million universes.”

I open my scuttle at night and see the far-sprinkled systems,

And all I see, multiplied as high as I can cipher, edge but the rim of the farther systems.

Wider and wider they spread, expanding and always expanding,

Outward and outward and forever outward. 
My sun has his sun, and round him obediently wheels,

He joins with his partners a group of superior circuit,

And greater sets follow, making specks of the greatest

inside them. (p. 51)

Whitman's descriptions of outer space have often led to misunderstandings:

Speeding through space. ... speeding through heaven

and the stars,

Speeding amid the seven satellites and the broad

ring and the diameter of eight thousand miles. . . (p. 37)

Joseph Beaver corrected Alice Cook's assumption that Whitman's "broad ring" referred to the discovery of the inner ring of Saturn by turning our attention to Mitchell's lectures on astronomy. ${ }^{7}$ Beaver does present a convincing case for how these lectures provided Whitman with figures, vocabulary, and imagery; however, Chambers devotes more than a page to a clear explanation of the rings, and one explanation may have reinforced the other.

Meanwhile, the condensation of the central mass would be going on, tending to produce a separation from what may now be termed the solidifying crust. During the contention between the attractions of these two bodies, or parts of one body, there would probably be a ring of attenuation between the mass and its crust. At length, when the central mass had reached a certain stage in its advance towards solidification, a separation would take place, and the crust would become a detached ring. It is clear, of course, that some law presiding over the refrigeration of heated gaseous bodies would determine the stages at which rings were thus formed and detached. We do not know any such law, but what we have seen assures us it is one observing and reducible to, mathematical formulae. (pp. 10-11)

We might note here that in 1860 Whitman also let us know he was aware of double stars and we find their importance in the nebular theory from Chambers. ${ }^{8}$

The nebular hypothesis, as it has been called, obtains a remarkable support in what would at first seem to militate against it - the existence in our firmament of several thousands of solar systems, in which there are more than one sun. These are called double and triple stars. Some double stars, upon which careful observations have been made, are found to have a regular revolutionary motion around each other in ellipses. (pp. 13-14)

Chambers fused two evolutionary concepts, and hard on the heels of his space discussion he began explanations of "The Constituent Materials of the Earth" and of "The Earth Formed-Era of the Primary Rocks." Several of Whitman's images may have been gleaned here. Chambers talks of the "original crystalline mass" of the earth and explains that "the earliest stratified rocks contain no matters which are not to be found in primitive granite." Although he acknowledged Charles Lyell's new classification of metamorphic rock, he continued to use the outmoded word "primary" and to emphasize the word "granite" in relation to it. This certainly seems to be Whitman's meaning when he writes:

My foothold is tenoned and mortised in granite,

I laugh at what you call dissolution,

And I know the amplitude of time. (p. 26) 
The sense of these lines would seem to be that granite is a "primitive" or first-formed rock, and Whitman would seem to be unaware of Lyell's contention that the four great classes of rocks may be considered to have been formed contemporaneously at every geological period. ${ }^{9}$

Chambers, when leading up to his conclusion that there is a democratic equality among planets, uses one of Whitman's favorite words, "tallies," and goes on to provide his arresting analogy between scientific and political realms in his description of the astronomical situation of the earth:

Uranus would be formed at the time when the heat of our system's matter was at the greatest, Saturn at the next, and so on. Now this tallies with the exceeding diffuseness of the matter of those elder planets. ... The tendency of the whole of the preceding considerations is to bring the conviction that our globe is a specimen of all the similarly-placed bodies of space. . . . It takes its place third in a series of planets, which series is only one of numberless other systems - forming one group. It is strikingly - if I may use such an expression-a member of a democracy. However, we cannot suppose that there is any peculiarity about it which does not probably attach to multitudes of other bodies -in fact, to all that are analogous to it in respect to cosmical arrangements. (pp. 23-24)

Not long after the celebration of positive science "Song of Myself" includes the lines:

I speak the password primeaval. . . . I give the sign of democracy;

By God! I will accept nothing which all cannot have their counterpart of on the same terms. (p. 29)

It would appear that science, the primitive worlds, and democracy are rapidly associated by the narrator, and perhaps Chambers supplied the spark that insured the pattern.

Another striking piece of information Whitman may have gathered from the Vestiges appears in these lines:

Rise after rise bow the phantoms behind me,

Afar down I see the huge first Nothing, the vapor

from the nostrils of death,

I know I was even there. ... I waited unseen and always,

And slept while God carried me through the lethargic mist,

And took my time. ... and took no hurt from the foetid carbon. (p. 50)

When Chambers is progressing from discussion of the formation of the earth to discussion of the common cement of organic life, he turns to the carboniferous formation.

There can be little doubt that the infusion of a large dose of this gas into the atmosphere at the present day would be attended by precisely the same circumstances as in the time of the carboniferous formation. Land animal life would not have a place on earth; vegetation would be enormous; and coal strata would be formed from the vast accumulations of woody matter, which would gather in every sea, near the mouths of great rivers. On the exhaustion of the superabundance of carbonic acid gas, the coal formation would cease, and the earth might again become a suitable theatre of being for land and animals. (p. 67) 
Such striking similarities of phrase strongly suggest that Whitman read Chambers. Although some scholars have written about Whitman's presumed use of Lamarckian evolution, ${ }^{10}$ Loren Eiseley pointed to Chambers' fundamental criticism of Jean Baptiste Lamarck's hypothesis when he called it "inadequate to account for the rise of organic kingdoms." 11 However, both Harry Gershenowitz ${ }^{12}$ and Lenny Emmanual ${ }^{13}$ have reminded us that Whitman was a synthesizer, and Charles Gillespie $^{14}$ demonstrated how long it took to disentangle the threads which led students of evolution to assume that Lamarck was a true precursor of Darwin. Therefore, it seems likely that Whitman's eclecticism could easily have allowed him to incorporate some of both sets of ideas without worrying about contradiction. However, he and Chambers were, beyond Lamarck, acutely aware of numerous possibilities for variation. Along with this awareness he shared with Chambers and a growing number of scientists a conviction that an understanding of the pervasiveness of the evolutionary design should make for a growth, rather than a diminution, in reverence for God. ${ }^{15}$ Chambers frequently expressed awe of a "creative Providence," and his frequent use of positive value words when discussing the "progressive" steps that had been taken towards the present is similar in tone to Whitman's.

Once Darwin published, his American adherents argued that evolution could be understood as underscoring "faith in reason, in progress, and in man." 16 But as early as 1855 , Whitman explained the universe as dynamic and ever-unfolding. It is in this sense that "I am an acme of things accomplished, and I am encloser of things to be" (p. 50) should be read. He believed that human beings were neither at the top of a statically created hierarch nor the final result of the ever on-going process. Rather, they were an interim development on a continuum that spanned eons into the past and into the future. The spiritual world could not then be a static, ultimate end; it would be what the continuously unfolding, evolutionary design bodied forth at each succeeding moment of existence.

Early in his career Whitman was comfortable with, at times even ecstatic about, the extent of geological time, and he fully accepted the interrelated development of the animal, vegetable, and mineral components of this globe. Since he shared these attitudes with Robert Chambers and at times resorted to very similar images and phrases to integrate his scientific ideas into his poetry, one may well surmise that Whitman's temperamental optimism and scientific curiosity found satisfaction in Vestiges and that it provided a foundation for his never-relinquished conviction that the flight has been towards the future from the beginning, from before (as he and Chambers understood it) the solidifying of nebulous mist into globes.

The University of Wisconsin, La Crosse

JUdith Kent GREeN

\section{NOTES}

1 Walt Whitman, Leaves of Grass, A Facsimile of the First Edition, ed. Richard Bridgman (San Francisco: Chandler, 1968). All references included parenthetically in the text are to this facsimile; page numbers are identical to those in the actual first edition.

2 Alice Lovelace Cooke, "Whitman's Indebtedness to the Scientific Thought of His Day," University of Texas Bulletin: Studies in English, 14 (1934), 89-115; Joseph C. Beaver, Walt Whitman: Poet of Science (New York: King's Crown Press, 1951). 
3 Loren Eiseley, Darwin's Century (Garden City, New York: Anchor Books, 1961), pp. 132-140; Arthur O. Lovejoy, "The Argument for Organic Evolution Before the Origin of Species, 1830-1858," in Forerunners of Darwin: 1745-1859, eds. Bentley Glass, Owsei Temkin, and William L. Straus, Jr. (Baltimore: Johns Hopkins, 1959), pp. 356-414; Milton Millhauser, fust Before Darwin: Robert Chambers and Vestiges (Middletown, CT: Wesleyan University Press, 1959). The phrase "in the air" comes from Millhauser.

4 [Robert Chambers], Vestiges of the Natural History of Creation, 2nd ed. (New York: 1845). Although Vestiges was first published in England in 1844, this is the first American edition; hereafter it will be cited parenthetically in the text.

5 Floyd Stovall, The Foreground of Leaves of Grass (Charlottesville: University Press of Virginia, 1974), pp. 152-154.

6 Milton Millhauser, "The Literary Impact of Vestiges of Creation," Modern Language Quarterly, 17 (1956), 213-226.

7 Beaver, pp. 57-58.

8 Walt Whitman, Leaves of Grass, A Facsimile of the 1860 Edition, ed. Roy Harvey Pearce (Ithaca, New York: Cornell University Press, 1961), p. 310.

9 Charles Lyell, Elements of Geology (London: 1838), p. 19.

10 David Charles Leonard, "Lamarckian Evolution in Whitman's 'Song of Myself," Walt Whitman Review, 24 (1978), 21-28; Edward J. Pfeifer, "The Theory of Evolution and Whitman's 'Passage to India," ESQ 42 (1961), 31-35; James T. F. Tanner, "The Lamarckian Theory of Progress in Leaves of Grass," Walt Whitman Review, 9 (1963), 3-11, and "The Superman in Leaves of Grass," Walt Whitman Review, 11 (1965), 85-100.

11 Eiseley, pp. 177-178.

12 Harry Gershenowitz, "Whitman and Lamarck Revisited," Walt Whitman Review, 25 (1979), 121-123.

13 Lenny Emmanual, "Whitman's Fusion of Science and Poetry," Walt Whitman Review, 17 (1971), 73-82.

14 Charles Coulston Gillespie, "Lamarck and Darwin in the History of Science" in Forerunners of Darwin: 1745-1859, pp. 265-291.

15 Gay Wilson Allen, "Walt Whitman's Long Journey Motif," Fournal of English and Germanic Philosophy, 38 (1939), 76-95.

16 Bert James Lowenberg, "Darwinism Comes to America, 1859-1900," Mississippi Valley Historical Review, 28 (1941-1942), 339-368. 